J. Lake Sci. (湖泊科学), 2014, 26(1):83-91

http : //www. jlakes. org. E-mail : jlakes@niglas. ac.cn

(C) 2014 by Journal of Lake Sciences

\title{
抚仙湖不同污染来源沉积物微生物解磷能力分析“
}

\author{
苏争光 $^{1,2}$, 冯慕华 ${ }^{2 * *}$, 宋媛媛 ${ }^{2}$, 金 星 $^{3}$, 马彦华 ${ }^{4}$, 李 勇 $^{1}$, 李文朝 ${ }^{2}$ \\ (1: 苏州科技学院,苏州 215009) \\ (2: 中国科学院南京地理与湖泊研究所湖泊与环境国家重点实验室, 南京 210008) \\ (3: 云南省玉溪市环境监测站,玉溪 653100) \\ ( 4 : 云南省玉溪市澄江县环境监测站,玉溪 653100)
}

\begin{abstract}
摘 要: 以云南抚仙湖为研究对象, 分析了不同污染来源沉积物微生物量、碱性磷酸酶活性 (APA) 和微生物解磷能力的 垂向分布特征和水平分布特征. 结果表明, 抗仙湖各采样点沉积物微生物生物量与 APA 垂向分布趋势相似, 总体上随着 深度增加逐渐降低, 微生物作用主要表现在表层. 在空间分布上, 富营养化星云湖以泄水为主的南岸隔河口微生物生物 量和 APA 最高, 其次为以农业面源污染为主的北岸梁王河口和以磷矿开发为污染来源的北岸东大河口, 再次为受人类活 动影响较小、以自生有机污染为主的湖心和东岸老凹嘴, 以自然水土流失为主的西岸尖山河口微生物生物量和 APA 最 低. 沉积物微生物生物量和 APA 体现了不同外源污染对抚仙湖各湖区的影响不同. 抚仙湖沉积物微生物对有机磷和无机 磷均有解磷能力, 并且无机磷解磷能力大于有机磷. 沉积物解无机磷细菌数量和 APA 决定了抚仙湖沉积物磷释放强度, 造成了抚仙湖较高强度的内源磷污染负荷.
\end{abstract}

关键词: 抚仙湖; 磷释放; 碱性磷酸酶活性; 解磷细菌; 微生物生物量

\section{Phosphate-solubilizing capability of microbes in the sediments from different pollution sources in Lake Fuxian}

\author{
SU Zhengguang ${ }^{1,2}$, FENG Muhua ${ }^{2}$, SONG Yuanyuan ${ }^{2}$, JIN Xing ${ }^{3}$, MA Yanhua ${ }^{4}$, LI Yong ${ }^{1} \&$ LI Wenchao $^{2}$ \\ (1: Suzhou University of Science and Technology, Suzhou 215009, P. R. China) \\ (2: State Key Laboratory of Lake Science and Environment, Nanjing Institute of Geography and Limnology, Chinese Academy \\ of Sciences, Nanjing 210008, P. R. China) \\ (3: Yuxi Institute of Environmental Science Research, Yuxi 653100, P. R. China) \\ (4: Chengjiang Institute of Environmental Science Research, Yuxi 653100, P. R. China)
}

\begin{abstract}
The vertical variations of microbial biomass, alkaline phosphatase activity (APA) and phosphate-solubilizing ability of microbes were studied in the sediments from different pollution sources in Lake Fuxian, Yunnan Province. The results showed that the microbial biomass and the APA in the sediment cores generally decreased with the depth and the strongest microbial activity was shown in the surface sediment. The microbial biomass and the APA in the sediments of the mouth of Gehe River in the south shore were the highest among the research sites, which was heavily polluted by the discharge from eutrophic Lake Xingyun. The second highest amounts of the microbial biomass and the APA were found in the sediments of the mouth of Liangwan River with agriculture pollution source and the sediments in the mouth of Dongda River with phosphate mining pollution source. However, the lowest amounts of the microbial biomass and the APA were shown in the sediments of the mouth of Jianshan River with the pollution source of soil erosion. The result of incubation experiment showed that the microbes in the sediments had stronger phosphate-solubilizing ability to dissolve inorganic phosphate than to dissolve organic phosphate. The combination of the amount of inorganic phosphate solubilizing bacteria and the APA determined the potential of phosphorus releasing from sediment, which resulted in high interior phosphorus loading in Lake Fuxian.
\end{abstract}

Keywords: Lake Fuxian; phosphorus releasing; alkaline phosphatase activity; phosphate-solubilizing bacteria; microbial biomass

* 国家自然科学基金项目(41171366) 资助. 2013-04-21 收稿;2013-06-07 收修改稿. 苏争光( 1986 ), 男, 硕士 研究生;E-mail:350431121@ qq. com.

** 通信作者;E-mail:mhfeng@ niglas. ac. cn. 
抚仙湖位于云贵高原云南省的中部, 属于典型的断陷型深水湖泊, 面积 $211 \mathrm{~km}^{2}$, 最大水深 $155 \mathrm{~m}$, 是滇 中地区水质最好、水量最大的淡水蓄积库 ${ }^{[1]}$. 但从 $1980 \mathrm{~s}$ 以来抚仙湖的营养水平在不断提高 ${ }^{[2]}$. 抚仙湖流域 磷矿资源的开发利用、农田化肥流失导致人湖磷污染物大量增加, 造成抚仙湖水质下降 ${ }^{[3]}$. 湖、库沉积物是 氮、磷等营养元素的重要蓄积库, 在一定条件下又是潜在的二次污染源 ${ }^{[5]}$. 在湖泊外源磷污染得到控制后, 磷的内源负荷受到越来越多的关注 ${ }^{[4-5]}$.

沉积物内源磷的释放受到众多环境因素的影响, 在不同的沉积物扰动、间隙水磷浓度、 $\mathrm{pH}$ 、温度、氧化还 原条件、光照、微生物等物理、化学及生物作用下, 会表现出不同的迁移转化特征 ${ }^{[6-8]}$. 其中微生物作用是沉 积物内源磷释放的重要因素 ${ }^{[9]}$. 孙晓杭等 ${ }^{[10]}$ 的研究表明微生物在沉积物内源磷的释放过程中起着重要作 用; 叶琳琳等 ${ }^{[11]}$ 研究了巢湖沉积物微生物在磷循环中的作用, 发现微生物可以直接或者间接影响沉积物中 磷形态的相互转换. 李宝等 ${ }^{[12]}$ 对滇池福保湾间隙水氮、磷分布和沉积物微生物间相互关系进行了研究, 认为 微生物是影响沉积物中氮、磷营养盐形态转化的重要因素之一. 在抚仙湖的沉积物中也发现了磷释放的现 象 ${ }^{[13]}$. 本文通过对抚仙湖不同污染来源沉积物中微生物生物量、碱性磷酸酶活性和沉积物微生物解磷能力 的垂直分布特征进行分析, 探讨其中的磷在微生物作用下的释放潜力.

\section{1 材料和方法}

\section{1 样品采集}

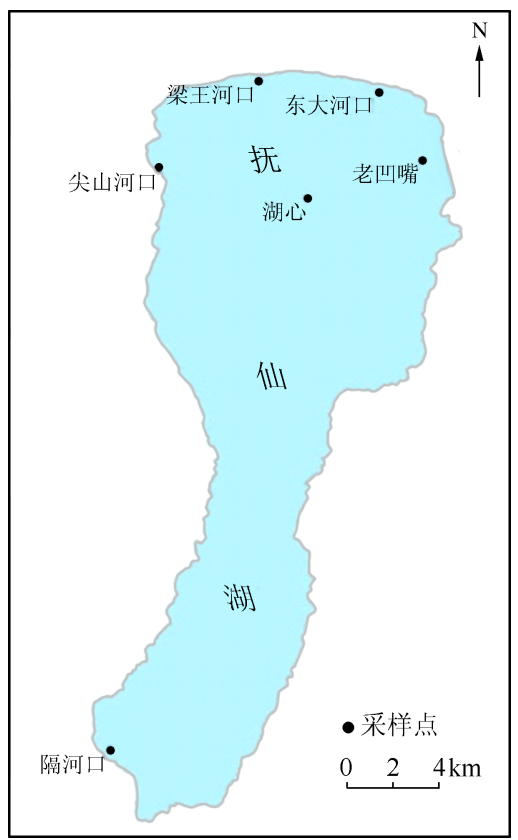

图 1 抚仙湖采样点位置

Fig. 1 Location of sampling sites in Lake Fuxian

在抚仙湖北部湖区分别代表水土流失污染区 ${ }^{[14]}$ 、农业面源污 染区 ${ }^{[15]}$ 、磷矿开发污染区 ${ }^{[16]}$ 和轻污染区的尖山河口 $\left(24^{\circ} 35^{\prime} 33^{\prime \prime} \mathrm{N}\right.$, $\left.102^{\circ} 52^{\prime} 57^{\prime \prime} \mathrm{E}\right) 、$ 梁王河口 ( $\left.24^{\circ} 37^{\prime} 47^{\prime \prime} \mathrm{N}, 102^{\circ} 52^{\prime} 57^{\prime \prime} \mathrm{E}\right)$ 、东大河口 $\left(24^{\circ} 37^{\prime} 31^{\prime \prime} \mathrm{N}, 102^{\circ} 55^{\prime} 38^{\prime \prime} \mathrm{E}\right)$ 、老凹嘴 $\left(24^{\circ} 36^{\prime} 01^{\prime \prime} \mathrm{N}, 102^{\circ} 56^{\prime} 35^{\prime \prime} \mathrm{E}\right)$ 及其湖心最深处 $\left(24^{\circ} 35^{\prime} 10^{\prime \prime} \mathrm{N}, 102^{\circ} 54^{\prime} 02^{\prime \prime} \mathrm{E}\right)$ 和南部湖区的隔河 口 $\left(24^{\circ} 22^{\prime} 54^{\prime \prime} \mathrm{N}, 102^{\circ} 49^{\prime} 38^{\prime \prime} \mathrm{E}\right.$ ) 布设沉积物采样点 (图 1), 于 2012 年 5 月用深水重力采泥器 $(\varphi 11 \mathrm{~cm})$ 采集沉积物柱状样. 由于沉 积物物理性状不同, 所采集沉积物深度也有所不同. 现场测定采 样点水深、透明度, 并测定沉积物上覆水溶解氧 ( DO) 、总磷 ( TP) 浓度.

\section{2 样品的处理与测定}

1.2.1 样品的处理 沉积物样品采集后运回抚仙湖北岸的中国 科学院南京地理与湖泊研究所抚仙湖工作站于阴暗处静置 $2 \mathrm{~h}$ 后分样. 各沉积物表层 $0 \sim 4 \mathrm{~cm}$ 按 $0.5 \mathrm{~cm}$ 进行分层, $4 \mathrm{~cm}$ 以下按 $1 \mathrm{~cm}$ 分层. 将分层样品依次放人聚乙烯自封袋中, 排出空气, 冷 藏保存. 部分样品冷冻干燥后研磨过 200 目筛, 备用.

1.2 .2 样品的测定 水深、透明度和 DO 分别用测深仪、塞氏盘 和碘量法直接测定, TP 用钼钩抗比色法测定 (各采样点基本理 化性状见表 1 ). 沉积物有机质 (OM) 依据土壤有机质测定法 ( GB/T 9834-1988) 测定. 沉积物生物量碳采用氯仿熏蒸一硫酸 钾提取的方法进行测定 ${ }^{[17]}$.

解磷细菌和细菌总数的计数采用林启美等的方法 ${ }^{[18]}$, 解无 机磷细菌固体培养基为: 葡萄糖 $10 \mathrm{~g}$ 、酵母粉 $0.5 \mathrm{~g} 、 \mathrm{CaCl}_{2} 0.1 \mathrm{~g}$ 、 $\mathrm{MgSO}_{4} \cdot 7 \mathrm{H}_{2} \mathrm{O} 0.3 \mathrm{~g}$ 、蒸馏水 $1000 \mathrm{ml}$ 、琼脂 $20 \mathrm{~g}$, 灭菌, 临用时每 $50 \mathrm{ml}$ 中加人 $10 \mathrm{ml} 10 \%$ 的 $\mathrm{CaCl}_{2}$ 和 $1 \mathrm{ml} 10 \%$ 的 $\mathrm{K}_{2} \mathrm{HPO}_{4}$, 调节 $\mathrm{pH}$ 为 7.0. 解有机磷细菌固体培养基为:蛋白胨 $10 \mathrm{~g}$ 、牛肉膏 $3 \mathrm{~g} 、 \mathrm{NaCl} 0.5 \mathrm{~g}$ 、琼脂 $18 \mathrm{~g}$ 、蒸 馏水 $1000 \mathrm{ml}, \mathrm{pH} 7.2$, 灭菌, 临用前每 $50 \mathrm{ml}$ 中加人新鲜蛋黄液 $3 \mathrm{ml}$ (蛋黄与无菌生理盐水等比例混合). 按 照常规 10 倍稀释法稀释表层 $1 \mathrm{~cm}$ 处沉积物样品, 分别取 $10^{-4} 、 10^{-5} 、 10^{-6} 3$ 个稀释梯度的样品 $50 \mu \mathrm{l}$ 涂布于 无机磷 (IP) 和有机磷 ( OP) 固体培养基平板上, 有机磷培养基在 $28^{\circ} \mathrm{C}$ 培养 $2 \mathrm{~d}$, 无机磷细菌培养 $7 \mathrm{~d}$. 具有透 明溶磷圈的菌落视为具有解磷活性的菌落, 计解磷细菌数量; 而没有透明圈的菌落视为一般细菌, 一般细菌 
和解磷细菌的总和计为细菌总数.

碱性磷酸酶活性 (APA) 采用略加改动的 Anupama 方法测定 ${ }^{[19]}$ : 称取约相当于 $0.2 \mathrm{~g}$ 干重的沉积物鲜 样, 加人 $4 \mathrm{ml} \mathrm{pH}$ 为 8.0 的三差甲基氨基甲烷盐酸盐( Tris-HCl) 中, 振荡混合均匀后超声处理 $45 \mathrm{~s}$. 在混合物 中加人 $1 \mathrm{ml}$ 对硝基苯酚 ( pNPP) 溶液作为底物, 完全混合后在 $37^{\circ} \mathrm{C}$ 水浴中加热反应 $1 \mathrm{~h}$. 反应完全后加人 $1 \mathrm{ml} 1 \mathrm{~mol} / \mathrm{L} \mathrm{NaOH}$ 溶液使反应停止. 以 5000 转/ $\mathrm{min}$ 的速度离心 $10 \mathrm{~min}$, 收集上清液, 以不加沉积物的反应 体系为空白, 然后用紫外可见分光光度计在 $410 \mathrm{~nm}$ 下测定吸光度. 测定沉积物含水率, APA 以每小时每千 克干重沉积物产生的对硝基苯酚毫克数表示.

解磷能力依照申琳子等所用的方法进行测定 ${ }^{[20]}$, 将稀释度为 $10^{-1}$ 的沉积物样品悬浮液 $1 \mathrm{ml}$ 接种到灭 菌的有效磷培养基中, 于 $30^{\circ} \mathrm{C}$ 恒温箱中培养 $21 \mathrm{~d}$. 取出过滤, 滤液中加人 $0.1 \mathrm{~mol} / \mathrm{L} \mathrm{HCl} 15 \mathrm{ml}$, 振荡 $15 \mathrm{~min}$ 后加人无磷活性炭 $1 \mathrm{~g}$, 充分摇匀, 减压过滤至滤液清亮. 用钼锑抗比色法测定滤液中磷含量, 分别表征无机 解磷菌的解磷能力和有机解磷菌的解磷能力. 其中有效磷培养基采用蒙金娜培养基: 葡萄糖 $10 \mathrm{~g}$ 、 $\left(\mathrm{NH}_{4}\right)_{2} \mathrm{SO}_{4} 0.5 \mathrm{~g} 、 \mathrm{MgSO}_{4} \cdot 7 \mathrm{H}_{2} \mathrm{O} 0.3 \mathrm{~g} 、 \mathrm{CaCO}_{3} 5.0 \mathrm{~g} 、 \mathrm{NaCl} 0.3 \mathrm{~g} 、 \mathrm{KCl} 0.3 \mathrm{~g} 、 \mathrm{FeSO}_{4} \cdot 7 \mathrm{H}_{2} \mathrm{O} 0.03 \mathrm{~g}$ 、 $\mathrm{MnSO}_{4} \cdot 4 \mathrm{H}_{2} \mathrm{O} 0.03 \mathrm{~g}$ 、蒸馏水 $1000 \mathrm{ml}$. 每 $30 \mathrm{ml}$ 培养基中, 有机磷培养基中加人卵磷脂酒精溶液 $1 \mathrm{ml}$, 无机 磷培养基中加人羟基磷灰石 $50 \mathrm{mg}$,于 $110^{\circ} \mathrm{C}$ 灭菌 $30 \mathrm{~min}$.

\section{3 实验仪器和数据分析}

所用仪器主要有冻干机 (LABCONCO)、离心机 (Avanti Centrifuge J-26XP, 贝克曼公司, 美国)、紫外可见 分光光度计 (岛津 UV2450-日本)、无菌操作台和生化培养箱 ( QHZ-98A, 太仓市华美生化仪器厂).

采用 Excel 2007 对实验数据进行分析,并用 Origin 8.5 绘制数据图.

\section{2 结果与讨论}

\section{1 采样点沉积物理化特征}

各个采样点的沉积物随来源的不同特征也有所不同. 在抚仙湖尖山河流域, 水土流失严重, 人湖泥沙是 尖山河口的主要沉积物. 梁王河口主要受到农业面源的污染, 其沉积物主要来自农村生活污水和农业排

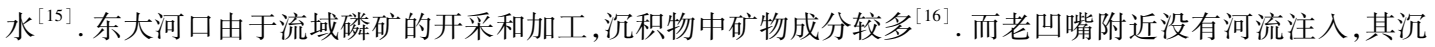
积物主要是自然沉降的产物. 湖心接受来自各方面的沉积物, 是各种污染物的总汇. 而南部湖区的隔河接受 来自富营养化严重的星云湖的泄水 ${ }^{[22]}$, 其沉积物中含大量有机质.

从各采样点基本理化性状分析结果可以看出 (表 1 ), 各采样点沉积物上覆水 TP 浓度范围为 $0.015 \sim$ $0.042 \mathrm{mg} / \mathrm{L}$, 属于湖库水环境质量标准 II III 类水质 ( GB/T 3838-2002), 而抚仙湖全湖水质属于水环境质 量 I 类标准, 说明抚仙湖湖底存在磷释放现象. 各个采样点沉积物 $\mathrm{pH}$ 均在 7 左右, 除隔河口和尖山河口沉积 物呈弱酸性外, 其它采样点沉积物均呈弱碱性. 从沉积物磷的形态来看, 沉积物中总磷主要成分为无机磷, 最高浓度出现在东大河口;隔河口沉积物总磷浓度也较高, 而且有机磷含量高于其它采样点.

表 1 抚仙湖采样点上覆水和沉积物基本理化性状

Tab. 1 Physico-chemical characteristics of the overlying water and sediment in the sampling sites of Lake Fuxian

\begin{tabular}{|c|c|c|c|c|c|c|c|c|c|}
\hline \multirow[b]{2}{*}{ 采样点 } & \multicolumn{4}{|c|}{ 上覆水 } & \multicolumn{5}{|c|}{ 沉积物 } \\
\hline & $\begin{array}{c}\text { 水深/ } \\
\mathrm{m}\end{array}$ & $\begin{array}{c}\text { 透明度/ } \\
\mathrm{m}\end{array}$ & $\begin{array}{c}\mathrm{TP} / \\
(\mathrm{mg} / \mathrm{L})\end{array}$ & $\begin{array}{c}\mathrm{DO} / \\
(\mathrm{mg} / \mathrm{L})\end{array}$ & $\mathrm{pH}$ & $\mathrm{Eh} / \mathrm{mV}$ & $\begin{array}{c}\mathrm{TP} / \\
(\mu \mathrm{mol} / \mathrm{g})^{\mathrm{a}}\end{array}$ & $\begin{array}{c}\mathrm{IP} / \\
(\mu \mathrm{mol} / \mathrm{g})^{\mathrm{a}}\end{array}$ & $\begin{array}{c}\mathrm{OP} / \\
(\mu \mathrm{mol} / \mathrm{g})^{\mathrm{a}}\end{array}$ \\
\hline 尖山河口 & 40 & 6.5 & 0.015 & 6.41 & $6.49 \sim 6.81$ & $-155 \sim-100$ & $10.86 \sim 13.04$ & $7.15 \sim 7.92$ & $3.13 \sim 5.56$ \\
\hline 梁王河口 & 30 & 7.0 & 0.021 & 5.88 & $6.94 \sim 7.37$ & $-414 \sim-169$ & $25.41 \sim 37.54$ & $17.95 \sim 26.24$ & $7.29 \sim 12.28$ \\
\hline 东大河口 & 40 & 6.5 & 0.037 & 6.61 & $6.83 \sim 7.28$ & $-220 \sim-120$ & $56.79 \sim 425.48$ & $43.09 \sim 369.6$ & $13.70 \sim 55.87$ \\
\hline 凹嘴 & 70 & 7.0 & 0.033 & 6.10 & $7.08 \sim 7.32$ & $-200 \sim-89$ & $27.41 \sim 42.27$ & $16.64 \sim 22.64$ & $8.61 \sim 19.64$ \\
\hline 湖心 & 150 & 6.5 & 0.017 & 5.69 & $7.00 \sim 7.25$ & $-286 \sim-159$ & $31.38 \sim 34.44$ & $9.55 \sim 24.72$ & $9.55 \sim 11.72$ \\
\hline 河口 & 30 & 6.5 & 0.042 & 5.99 & $6.70 \sim 6.86$ & $-223 \sim-136$ & $70.14 \sim 113.71$ & $52.90 \sim 91.66$ & $17.24 \sim 31.62$ \\
\hline
\end{tabular}

a 参考文献 $[21]$ 的数据.

沉积物有机质含量是反映湖泊营养水平的重要指标之一, 在一定程度上能够衡量湖泊的污染程度. 抚 
仙湖不同沉积物有机质含量存在差异 (图 2), 但垂向分布趋势较为相似, 基本表现为表层高, 随深度增加逐 渐降低. 沉积物表层 $10 \mathrm{~cm}$ 有机质含量较高且波动较大, 故取表层 $10 \mathrm{~cm}$ 有机质含量的平均值从高到低依次 为:梁王河口 $(4.7 \%) 、$ 湖心 $(3.6 \%)$ 、隔河口 (3.4\%)、尖山河口 $(2.8 \%)$ 、老凹嘴 $(2.6 \%)$ 、东大河口 $(2.4 \%)$. 其中梁王河口、湖心和隔河口表层有机质含量最高值在 $6 \%$ 左右, 与中富营养水平的南京玄武湖表 层沉积物有机质含量相当 ${ }^{[23]}$, 可见抚仙湖污染程度已不容小视. 丰富的有机质为微生物的生长繁殖提供了 有利条件,使微生物作用成为沉积物磷释放的主要影响因素.
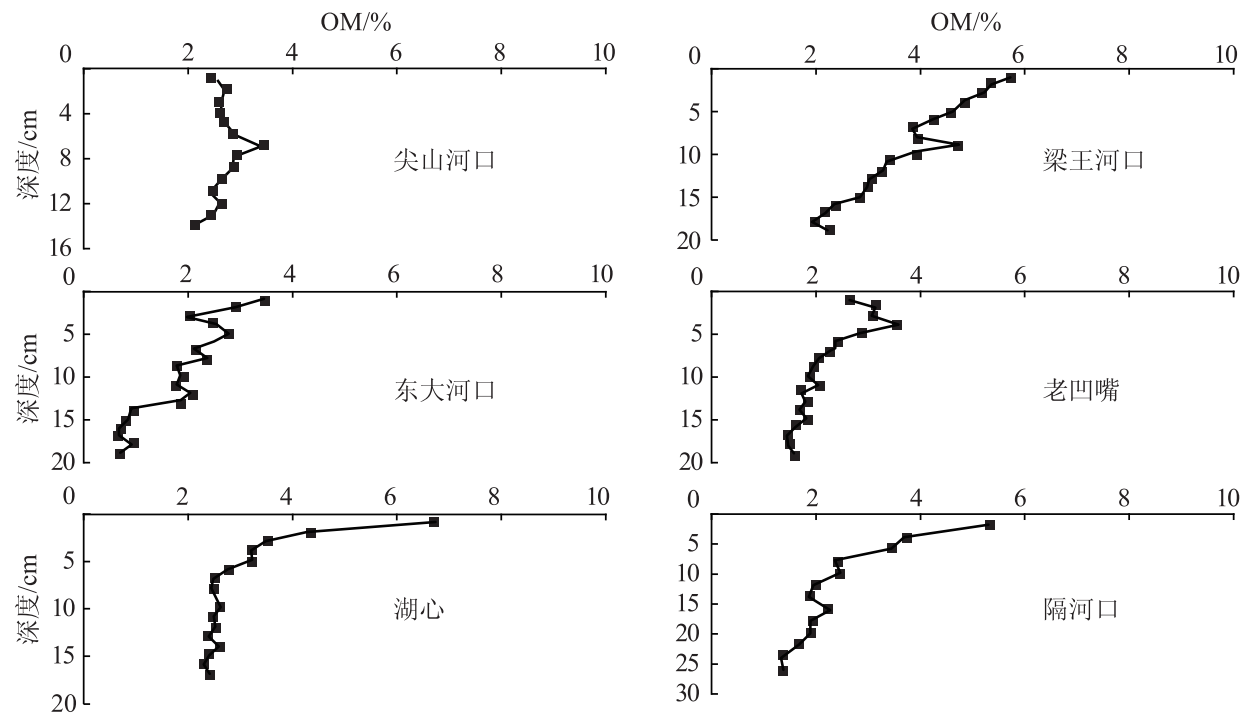

图 2 抚仙湖沉积物中有机质含量的垂向变化

Fig. 2 Vertical variation of organic matter content in the sediments of Lake Fuxian

\section{2 沉积物微生物生物量变化}

土壤微生物生物量碳是土壤有机质的重要来源, 同时又是土壤中易被矿化和转化的部分, 是评价土壤 微生物量和活性的重要指标 ${ }^{[24]}$, 而沉积物中微生物生物量碳是沉积物有效营养盐活性库的主要部分, 研究 湖泊沉积物微生物生物量的大小和分布对了解水体富营养化程度具有重要意义 ${ }^{[25]}$.

抚仙湖各采样点微生物生物量垂向变化趋势不同, 梁王河口和隔河口沉积物表层微生物生物量远高于 底层, 其它采样点沉积物微生物生物量的垂直分布较为稳定 (图 3). 由于采样深度不同, 取表层 $10 \mathrm{~cm}$ 沉积 物样品求平均值, 其含量分布从高到低依次为: 梁王河口 $(285.12 \mathrm{mg} \mathrm{C} / \mathrm{kg})$ 、隔河口 $(239.23 \mathrm{mg} \mathrm{C} / \mathrm{kg})$ 、老凹 嘴 $(188.02 \mathrm{mg} \mathrm{C} / \mathrm{kg}) 、$ 东大河口 $(110.32 \mathrm{mg} \mathrm{C} / \mathrm{kg}$ )、湖心 $(79.21 \mathrm{mg} \mathrm{C} / \mathrm{kg}$ )、尖山河口 $(25.32 \mathrm{mg} \mathrm{C} / \mathrm{kg})$. 与浅 水湖泊不同 ${ }^{[25]}$, 抚仙湖微生物生物量的分布与有机质含量的关系不是很显著, 例如抚仙湖最深点一一湖心 有机质浓度虽较高, 但其微生物生物量却较低; 而湖岸带受人为活动影响较小的老凹嘴采样点沉积物中有 机质含量较低, 但微生物生物量却较高. Dobbs 的研究也发现深海微生物生物量碳与有机质含量的水平分布 没有显著相关性 ${ }^{[26]}$, 这说明微生物生物量的分布与其水体深度有一定的关系. 梁王河口和隔河口微生物生 物量高, 这与武汉东湖沉积物中有大量生活污水排人的采样点的微生物生物量分布类似 ${ }^{[27]}$; 而尖山河口和 东大河口微生物生物量较低, 主要是由于这两个区域有机质含量较低.

\section{3 抚仙湖沉积物解磷细菌分布}

各个采样点沉积物中均存在大量的分解卵磷脂和磷酸钙的细菌, 且解有机磷细菌的数量大于解无机磷 细菌的数量. 但不同沉积物中解磷细菌数量有所不同: 老凹嘴、隔河口和湖心沉积物中解有机磷细菌较多, 达 $10^{6} \mathrm{cfu} / \mathrm{g}$; 而东大河口、梁王河口和尖山河口沉积物中解有机磷细菌数量要比老凹嘴低一个数量级. 隔河 口沉积物中解无机磷细菌最多, 达 $10^{5} \mathrm{cfu} / \mathrm{g}$; 其次为老凹嘴、梁王河口和湖心, 达到 $10^{4} \mathrm{cfu} / \mathrm{g}$; 而尖山河口和 东大河口沉积物中解无机磷细菌最低, 为 $10^{3} \mathrm{cfu} / \mathrm{g}$. 各采样点解磷细菌占细菌总数的比例也不一样: 老凹 

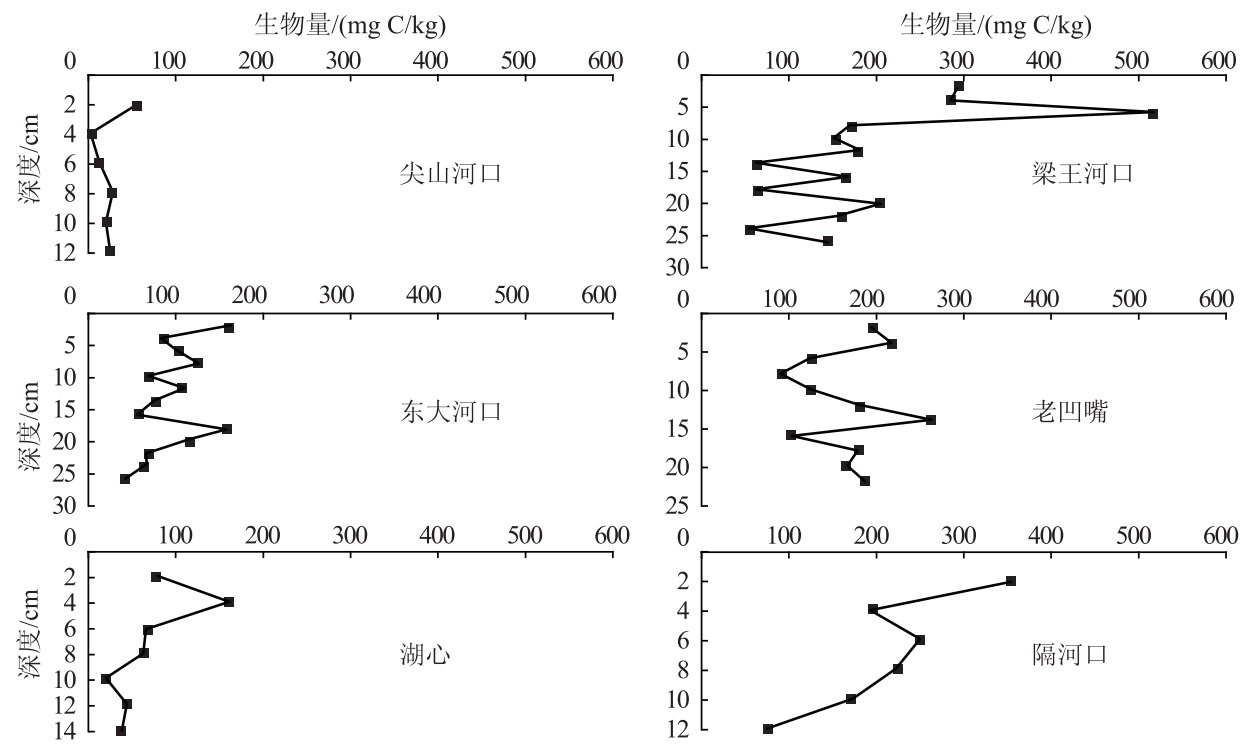

图 3 抚仙湖沉积物微生物生物量的垂向变化

Fig. 3 Vertical distribution of microbial biomass in the sediments of Lake Fuxian

嘴、东大河口和湖心沉积物中解有机磷细菌占细菌总数均在 $30 \%$ 以上; 而梁王河口、尖山河口和隔河口沉积 物中解有机磷细菌占细菌总数的比例均在 $15 \%$ 以下. 老凹嘴沉积物中解无机磷细菌占细菌总数的 $13 \%$; 而 其它点均在 $5 \%$ 以下 (表 2). 沉积物解磷菌的数量与有机磷、有机质和微生物生物量不存在直接关联. 其原 因比较复杂, 这可能与沉积物中碳源、氮源种类有关, 或者与沉积物酸碱度、含水率和扰动程度等因素 有关 ${ }^{[18]}$.

表 2 抚仙湖表层沉积物解磷细菌分布

Tab. 2 Distribution of phosphate-solubilizing bacteria in the surface sediments of Lake Fuxian

\begin{tabular}{ccrccrc}
\hline 采样点 & $\begin{array}{c}\text { 解有机磷细菌/ } \\
\left(\times 10^{5} \mathrm{cfu} / \mathrm{g}\right)\end{array}$ & $\begin{array}{c}\text { 细菌总数 } \\
\left(\times 10^{5} \mathrm{cfu} / \mathrm{g}\right)\end{array}$ & $\begin{array}{c}\text { 解有机磷细菌 } \\
\text { 占细菌总数比例 }\end{array}$ & $\begin{array}{c}\text { 解无机磷细菌/ } \\
\left(\times 10^{5} \mathrm{cfu} / \mathrm{g}\right)\end{array}$ & $\begin{array}{c}\text { 细菌总数/ } \\
\left(\times 10^{5} \mathrm{cfu} / \mathrm{g}\right)\end{array}$ & $\begin{array}{c}\text { 解无机磷细菌 } \\
\text { 占细菌总数比例 }\end{array}$ \\
\hline 尖山河口 & $1.67 \pm 0.35$ & $16.71 \pm 0.42$ & $10 \%$ & $0.05 \pm 0.01$ & $1.05 \pm 0.11$ & $5 \%$ \\
梁王河口 & $2.41 \pm 0.32$ & $17.62 \pm 0.83$ & $13 \%$ & $0.31 \pm 0.11$ & $10.45 \pm 0.41$ & $3 \%$ \\
东大河口 & $3.30 \pm 0.18$ & $9.82 \pm 0.61$ & $33 \%$ & $0.037 \pm 0.012$ & $0.74 \pm 0.02$ & $2 \%$ \\
老凹嘴 & $46.24 \pm 2.57$ & $110.47 \pm 8.76$ & $42 \%$ & $0.67 \pm 0.04$ & $4.87 \pm 0.31$ & $13 \%$ \\
湖心 & $12.13 \pm 0.24$ & $40.39 \pm 2.86$ & $30 \%$ & $0.14 \pm 0.02$ & $3.84 \pm 0.19$ & $4 \%$ \\
隔河口 & $14.02 \pm 1.41$ & $97.38 \pm 6.72$ & $14 \%$ & $1.28 \pm 0.32$ & $55.78 \pm 0.30$ & $2 \%$ \\
\hline
\end{tabular}

\section{4 沉积物碱性磷酸酶活性分布特征}

细菌依靠其特有的酶体系能把沉积物中不溶态有机磷和不溶态磷化合物转化为可溶性磷, 碱性磷酸酶 是该体系中重要的微生物酶之一. 因此 APA 的大小反映了沉积物磷的释放潜力 ${ }^{[28]}$.

抚仙湖不同污染来源沉积物中 APA 各不相同, 但其垂向分布相似 (图 4), APA 最高点均出现在沉积物 表层 $0 \sim 2 \mathrm{~cm}$ 处, 在 $0 \sim 10 \mathrm{~cm}$ 内 APA 较高且变化较大, $10 \mathrm{~cm}$ 以下 APA 较低且趋于稳定. 因此取沉积物表层

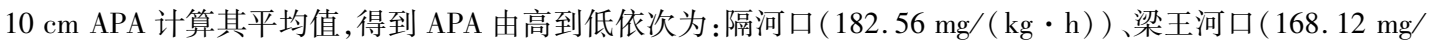
$(\mathrm{kg} \cdot \mathrm{h})$ )、老凹嘴 $(141.41 \mathrm{mg} /(\mathrm{kg} \cdot \mathrm{h}))$ 、东大河口 $(104.52 \mathrm{mg} /(\mathrm{kg} \cdot \mathrm{h}))$ 、湖心 $(89.69 \mathrm{mg} /(\mathrm{kg} \cdot \mathrm{h}))$ 、尖山 河口 $(47.57 \mathrm{mg} /(\mathrm{kg} \cdot \mathrm{h}))$. 从总体来看, 抚仙湖沉积物 APA 垂直分布与太湖、云龙湖等浅水湖泊相似 ${ }^{[29-30]}$, 均为表层高于底层. 究其原因, 沉积物表层营养成分相对富足, 微生物生物量较大, 能够分泌较多的酶. 从各 
个采样点来看, 梁王河口和南部湖区隔河口沉积物 APA 最高, 主要是由于梁王河口和隔河口有机污染严重, 微生物生物量较大; 其次为老凹嘴, 这可能与该点附近水生植物含量较高有关, 有研究表明水生植物对沉积 物 APA 也有一定影响 ${ }^{[30]}$; 而东大河口沉积物 APA 较低,一方面是由于其微生物生物量小, 不能大量分泌 酶, 另一方面是由于东大河上游有磷矿开发的历史, 其径流磷酸盐含量较高, 致使东大河水体中磷酸盐含量 也较高, 而碱性磷酸酶是一种诱导酶, 水中较高磷酸盐含量也能抑制碱性磷酸酶的活性. 湖心和尖山河口沉 积物 APA 也很低,与这两点微生物生物量小有直接关系.
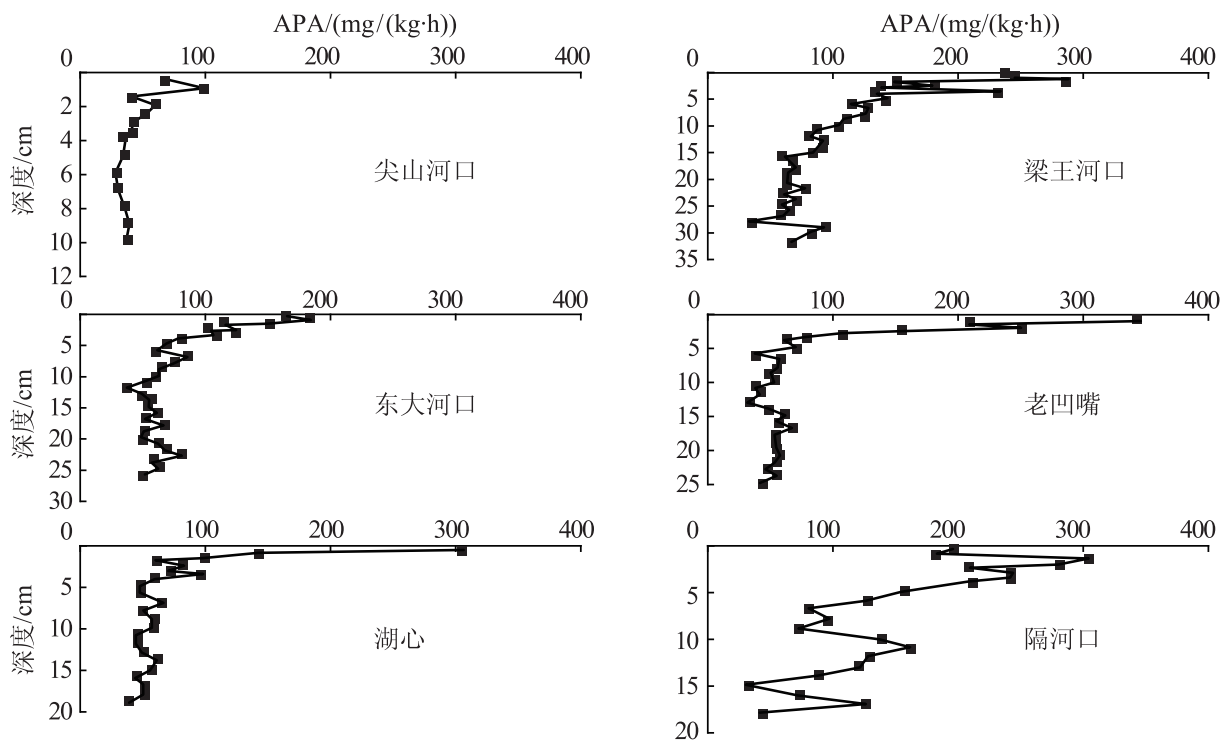

图 4 抚仙湖沉积物碱性磷酸酶活性的垂直分布

Fig. 4 Vertical distribution of alkaline phosphatase activity in the sediments of Lake Fuxian

\section{5 沉积物微生物解磷能力垂直分布特征}

研究细菌的解磷能力有多种方法, 本文采用对磷细菌进行液体培养, 测定培养液中可溶性磷含量, 通过 可溶性磷含量高低来判断解磷能力的大小的方法. 微生物解磷能力是在实验室条件下测得的, 而实际释放 量受温度、水深等多种因素的影响, 本研究虽不能代表抚仙湖各采样点沉积物中微生物解磷能力的实际情 况,但能够反映出不同污染来源沉积物磷释放潜力的大小.

各采样点微生物解无机磷能力存在较大差异, 南岸隔河口沉积物微生物解无机磷能力远高于北岸各采 样点, 其次依次为老凹嘴、湖心、东大河口, 而梁王河口和尖山河口沉积物微生物解无机磷能力最小 ( 图 5 ). 各采样点沉积物微生物解有机磷能力较为相近, 基本呈现为解无机磷能力大于解有机磷能力, 除东大河和 尖山河口外, 其它 4 个采样点沉积物微生物解有机磷和解无机磷浓度存在显著差异 $(P<0.05)$. 各采样点微 生物解有机磷能力的垂向分布较为相似, 随深度的波动较小, 基本呈现表层高于底层. 而各点微生物解无机 磷浓度的垂直波动较大, 变化趋势也各不相同. 尖山河口沉积物微生物解无机磷浓度最大值在表层; 而梁王 河口沉积物微生物解无机磷浓度最大值出现在底层沉积物中; 东大河口、老凹嘴、湖心和隔河口沉积物微生 物解无机磷浓度分别在表层和底层出现高值, 但表层沉积物解磷能力均大于底层. 宋媛媛等 ${ }^{[21]}$ 研究表明沉 积物中 OP 含量仅占 TP 的 $13 \%$ 43\% , 且垂向分布较为稳定, 与微生物解有机磷能力的垂向变化特征相似. 微生物对有机磷的分解主要是依靠碱性磷酸酶, 表层沉积物中碱性磷酸酶含量较高导致表层微生物解有机 磷能力较强. 沉积物中 IP 是 TP 的主要组成部分, 并且抚仙湖沉积物无机磷形态中易于被生物利用的可交换 态磷和铁磷的含量较少, 而不易于被生物利用的自生磷灰石、碎屑磷灰石、闭蓄态磷的含量较高 ${ }^{[21]}$. 在本研 究区域中, 东大河口沉积物解磷细菌数量虽然最少, 但 IP 含量远高于其它各采样点, 尤其是钙磷含量 ${ }^{[21]}$, 微 生物解无机磷能力依然居中, 表现出很强的磷释放能力. 而老凹嘴和隔河口沉积物无机磷含量低于东大河 
口沉积物, 尤其是钙磷含量少一个数量级 ${ }^{[21]}$, 但沉积物微生物解无机磷细菌数量较大, 沉积物微生物解磷能 力也最强. 梁王河口和湖心无机磷和各形态磷含量相当, 但其解无机磷能力差异较大, 梁王河口沉积物中解 无机磷细菌数量高于湖心, 但微生物解磷能力却低于湖心. 这可能是由于梁王河口主要受农业污染影响, 微 生物种类与受人类影响较小的湖心不同, 但造成两者沉积物均存在较强的磷释放能力, 上覆水磷浓度相当. 尖山河口的钙磷含量和解无机磷细菌数量均最低, 其微生物解磷能力相应最低.

不同污染来源和不同水深的沉积物中微生物解磷能力的分布特征较为复杂, 如结合微生物作用下沉积 物磷释放速率和培养体系生物理化参数动态变化规律研究 ${ }^{[31]}$, 可以进一步揭示微生物对沉积物无机磷的分 解机理.

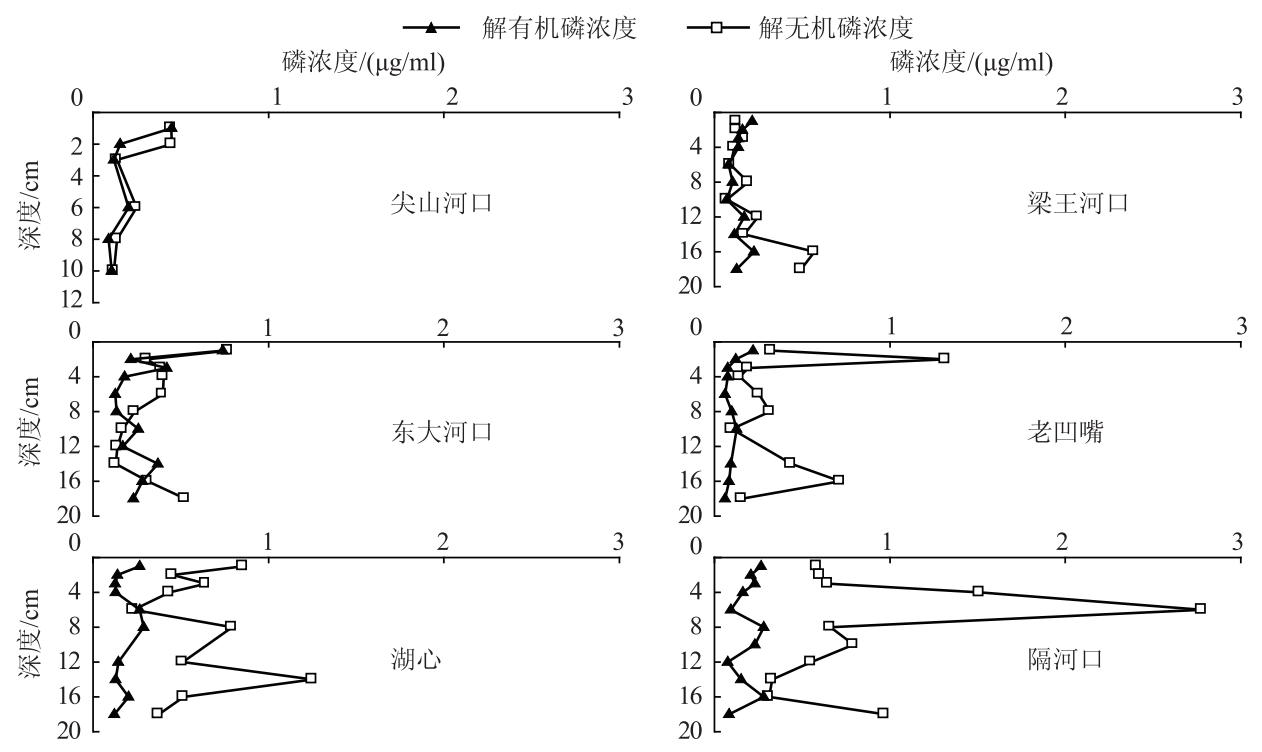

图 5 抚仙湖沉积物微生物解磷能力的垂直分布

Fig. 5 Vertical distribution of microbial phosphate-solubilizing ability in the sediments of Lake Fuxian

\section{6 沉积物上覆水磷浓度和微生物、碱性磷酸酶活性之间的相关性}

由于沉积物磷释放直接体现在沉积物上覆水磷浓度, 因此将抚仙湖不同区域沉积物上覆水 TP 浓度与 沉积物有机质、微生物生物量、解磷能力和 APA 进行相关分析 (表 3), 以期获得影响沉积物磷释放的关键因 子. 结果表明, 抚仙湖沉积物上覆水 TP 浓度与解无机磷细菌数量、APA 呈显著正相关 (相关系数分别为 0.674 和 0.677 ), 说明沉积物解无机磷细菌和 APA 是决定抚仙湖沉积物磷分解和释放的关键因素, 这也验 证了 APA 可以反映沉积物磷的释放潜力这一结论 ${ }^{[28]}$; 但上覆水 TP 浓度与有机质 $(\mathrm{OM})$ 呈负相关, 大量有机 质输人可能与磷结合形成不易迁移的有机磷形态, 从而抑制了沉积物 TP 释放. 碱性磷酸酶活性与沉积物微 生物生物量和解无机磷细菌呈显著正相关 (相关系数分别为 0.899 和 0.846 ), 而与 OM 的相关性不显著, 这 与以往关于富营养化湖泊和浅水湖泊的研究结果不同 ${ }^{[12,28]}$. 由于抚仙湖流域磷矿开发影响, 抚仙湖沉积物 以无机磷输人为主, 从而使抚仙湖沉积物无机磷细菌对沉积物中 APA 的贡献率较大, 同时也影响了上覆水 TP 浓度.

\section{3 结论}

1 ) 在空间分布上, 微生物生物量和碱性磷酸酶活性的分布大小大致为隔河口 > 梁王河口 > 老凹嘴 $>$ 东 大河口 > 湖心 > 尖山河口, 而沉积物微生物解磷能力分布大小依次为隔河口 > 老凹嘴 $>$ 湖心 $>$ 东大河口 > 梁王河口 > 尖山河口. 微生物生物量、APA 和沉积物微生物解磷能力的空间分布差异与沉积物的外源污染、 水域深度等因素有关. 
表 3 抚仙湖沉积物上覆水总磷浓度和微生物、碱性磷酸酶活性之间的相关性

Tab. 3 Regression analysis of the concentrations of TP in the overlying water with the microbe and alkaline phosphatase activity in the sediments of Lake Fuxian

\begin{tabular}{|c|c|c|c|c|c|c|c|c|}
\hline & 上覆水 $\mathrm{TP}$ & $\begin{array}{l}\text { 解有机 } \\
\text { 磷能力 }\end{array}$ & $\begin{array}{l}\text { 解无机 } \\
\text { 磷能力 }\end{array}$ & OM & APA & $\begin{array}{l}\text { 微生物 } \\
\text { 生物量 }\end{array}$ & $\begin{array}{l}\text { 解有机 } \\
\text { 磷细菌 }\end{array}$ & $\begin{array}{l}\text { 解无机 } \\
\text { 磷细菌 }\end{array}$ \\
\hline 上覆水 TP & 1 & & & & & & & \\
\hline 解有机磷能力 & -0.201 & 1 & & & & & & \\
\hline 解无机磷能力 & 0.261 & $0.655^{*}$ & 1 & & & & & \\
\hline $\mathrm{OM}$ & -0.524 & 0.428 & -0.278 & 1 & & & & \\
\hline APA & $0.677^{*}$ & 0.390 & 0.506 & 0.122 & 1 & & & \\
\hline 微生物生物量 & 0.423 & 0.397 & 0.216 & 0.509 & $0.899^{* *}$ & 1 & & \\
\hline 解有机磷细菌 & 0.339 & -0.397 & 0.115 & -0.320 & 0.120 & 0.073 & 1 & \\
\hline 解无机磷细菌 & $0.674 *$ & 0.273 & $0.735^{*}$ & -0.248 & $0.846^{* *}$ & 0.603 & 0.450 & 1 \\
\hline
\end{tabular}

*表示 $P<0.1 ; * *$ 表示 $P<0.05 ; n=6$.

2) 东大河流域内沉积物表现出较强的解磷能力, 其沉积物蓄积的高浓度的钲磷是抚仙湖潜在的磷污染 来源. 梁王河口和尖山河口微生物生物量、碱性磷酸酶活性和解磷能力的高低, 反映人类活动造成了抚仙湖 水环境恶化.

3 ) 湖心沉积物有机质含量较高, 上覆水仅达到水环境质量标准的 II III 类水质 (GB/T 3838-2002), 表明湖心沉积物存在磷的释放现象. 受营养化星云湖泄水影响, 南岸隔河口沉积物中有机质含量、解磷菌数 量和碱性磷酸酶活性菌较高, 微生物解磷能力也较强. 目前抚仙湖营养水平逐年上升, 浮游藻类生物量逐年 增加,若不加以控制, 隔河口沉积物的污染现状可能成为抚仙湖的发展趋势.

\section{4 参考文献}

[ 1 ] 中国科学院南京地理与湖泊研究所. 抚仙湖. 北京:海洋出版社,1990.

[2] 夏天翔, 潘继征, 刘雪华等. 抚仙湖水体 NP 变化及其非点源污染特征. 农业环境科学学报, 2008, 27 (4): 1340-1345.

[ 3 ] 冯慕华, 郑 锦, 李文朝等. 云南省抚仙湖流域帽天山磷矿区磷流失过程模拟研究. 环境化学, 2007, 26 (6): 801-804.

[ 4] 高 丽,杨 浩, 周健民等. 滇池沉积物磷内负荷及其对水体贡献的研究. 环境科学学报,2004,24(5):776-781.

[ 5 ] 赵兴青,杨柳燕,于振洋等. 太湖沉积物理化性质及营养盐的时空变化. 湖泊科学, 2007,19(6):698-704.

[ 6 ] Gao L, Zhou JM, Yang H et al. Phosphorus fractions in sediment profiles and their potential contributions to eutrophication in Dianchi lake. Environmental Geology, 2005,48 :835-844.

[ 7 ] Pettersson K. Phosphorus characteristics of settling and suspended particles in Lake Erken. Science of the Total Environment, $2001,266: 79-86$.

[ 8 ] Ullman WJ, Sandstrom MW. Dissolved nutrient fluxes from the nearshore sediments of Bowling Green Bay, central Great Barrier Reef Lagoon (Australia). Estuarine, Coastal and Shelf Science, 1987,24:289-303.

[ 9 ] 韩沙沙,温琰茂. 富营养化水体沉积物中磷的释放及其影响因素. 生态学杂志,2002,23(2):98-101.

[10] 孙晓杭, 张 昱, 张斌亮等. 微生物作用对太湖沉积物磷释放影响的模拟试验研究. 环境化学, 2006,25(1):24-27.

[11] 叶琳琳, 朱 燕, 徐圣友. 微生物对巢湖沉积物生物可利用性磷的稳定性影响. 资源环境与工程, 2007,21 (3): 339-343.

[12] 李 宝,丁世明, 范成新等. 滇池福宝湾间隙水氮磷分布及其与底泥微生物和磷酸酶相互关系. 湖泊科学, 2008, 20 (4) $: 420-427$.

[13] 王建云,普发贵. 抚仙湖垂向水质状况及特征研究.玉溪师范学院学报,2003,19:53-57.

[14] 孙孝龙, 蒋文举, 王克勤等. 抚仙湖尖山河小流域山地典型地类非点源污染特征与分析. 环境科学学报, 2009,29 (7) : 1534-1541.

[15] 蒋鸿昆, 高海鹰, 张 齐等. 抚仙湖梁王河流域农业耕作与流域水质响应关系研究. 环境科学, 2007, 28 (10): 
2294-2300.

[16] 冯慕华,潘继征,柯 凡等. 云南抚仙湖流域废弃磷矿区水污染现状. 湖泊科学, 2008,20(6): 766-772.

[17］李振高,骆永明,滕 应.土壤与环境微生物研究法. 北京:科学出版社,2008.

[18］林启美,赵小蓉,孙炎鍂等. 四种不同生态系统的土壤解磷菌数量及种群分布. 土壤与环境,2000,9(1):34-37.

[19] Anupama VN, Amrutha PN, Chitra GS et al. Phosphatase activity in anaerobic bioreactors for wastewater treatment. Water Research, $2008, \mathbf{4 2}: 2796-2802$.

[20］申琳子,冯慕华,李文朝等. 简单复旺对磷矿废弃地磷释放的影响模拟实验. 环境化学, 2010,29(6):1068-1074.

[21］宋媛媛,冯慕华,苏争光等. 抚仙湖不同来源沉积物磷形态垂向分布特征. 环境科学学报, 2013,33(9):2579-2589.

[22] 王晋虎, 张德华, 陈异晖. 星云湖流域畜禽粪便污染负荷及其环境影响. 上海环境科学, 2011, (1):12-17,22.

[23] 易文利, 王圣瑞, 杨苏文等. 长江中下游浅水湖泊沉积物腐殖质组分赋存特征. 湖泊科学, 2011,23(1):21-28.

[24] 李东坡,武志杰, 陈利军等. 长期培肥黑土微生物量碳动态变化及影响因素. 应用生态学报, 2004, 15 (8): 1334-1338.

[25] 毛海芳, 何 江, 吕昌伟等. 沉积物中微生物量与有机碳形态的相关性研究. 农业环境科学学报, 2010,29(12): 2406-2412.

[26] Dobbs FC. Sedimentary microbes of the equatorial Pacific Ocean. Miami Beach, Florida, USA: General Meeting of the American Society for Microbiology, 1997:385.

[27] 冯 峰, 王 辉, 方 涛等. 东湖沉积物中微生物量与碳、氮、磷的相关性. 中国环境科学, 2006,26(3):342-345.

[28] 章曦婷, 王晓蓉, 金相灼. 太湖沉积物中碱性磷酸酶活力 (APA) 和磷形态的垂向特征及相关性. 农业环境科学学 报,2007,26(1) :36-40.

[29] 徐德兰, 万 蕾, 高明侠等. 骆马湖东部沉积物中氮磷含量和碱性磷酸酶活性季节变化. 农业环境科学学报, 2012, 31( 7 ) : 1387-1392.

[30] 董 潇, 王 晓, 宋新桓等. 云龙湖沉积物碱性磷酸酶活力特征及其对氮、磷元素的作用. 湿地科学, 2009,7(4): 368-371.

[31 ] Feng MH, Ngwenya BT, Wang L et al. Bacterial dissolution of fluorapatite as a possible source of elevated dissolved phosphate in the environment. Geochimica et Cosmochimica Acta, 2011,75:5785-5796.

[32] 高 光, 秦伯强, 朱广伟. 太湖梅梁湾中碱性磷酸酶活性及其与藻类生长的关系. 湖泊科学, 2004,16(3):245-251. 